\title{
Supramolecular helix of an amphiphilic pyrene derivative induced by chiral tryptophan through electrostatic interactions
}

Jinchong Xiao, Jialiang Xu, Shuang Cui, Huibiao Liu, Shu Wang, Yuliang Li*

Beijing National Laboratory for Molecular Sciences, Key Laboratory of Organic

Solids, Center for Molecular Sciences, Institute of Chemistry, Chinese Academy of

Sciences, Beijing 100080, P.R. China

Corresponding author: ylli@iccas.ac.cn

\section{Contents}

Materials and methods page S2-S3

Figure S1 and S2 page S4

Synthetic section page S4-S9

Figure S3-S16 page S10-S18 


\section{Experimental Section}

\section{Materials and Methods}

Most of the chemical reagents were purchased from Acros or Aldrich Corporation. Anhydrous solvents were purified using the standard procedure. $\mathrm{Et}_{3} \mathrm{~N}$ and $\mathrm{CH}_{2} \mathrm{Cl}_{2}$ were purified by drying over $\mathrm{CaH}_{2}$, followed by distillation. Toluene and THF were distilled from sodium and benzophenone. Chromatographically pure ethanol was commercially obtained and used without further purification. Column chromatography was performed on silica gel (200-300 mesh).

UV-vis spectra were recorded on a Jasco V-570 spectrometer, and fluorescence (FL) spectra were measured on a Jasco FP-6000 spectrofluorometer. ${ }^{1} \mathrm{H}$ NMR and ${ }^{13} \mathrm{C}$ NMR spectra were obtained on Bruker 400/600 spectrometers. MALDI-TOF mass spectrometric measurements were performed on Bruker Biflex MALDI-TOF. Circular dichroism (CD) spectra were conducted on a JASCO J-815 spectrophotometer. Scanning electron micrographs (SEM) measurement was performed with a JSM 6700 F NT. The size distributions of the complexes dispersed in mixture solvent were evaluated by the dynamic light scattering (DLS) technique using a particle size analyzer (BI-90Plus, Brookhaven Instruments Corp., Holtsville, NY) with a scattering angle of $90^{\circ}$.

Aggregation behavior of the complex was studied by dissolving a molecular solution of $\mathbf{P y D N H}_{3}$ in ethanol $\left(7.27 \times 10^{-4} \mathrm{M}\right)$ into ultrapure water, which gave a final ethanol/water ratio of 8:92 (v/v). After the solutions were allowed to equilibrate over $20 \mathrm{~min}$, the aggregation structure was investigated by using UV-vis, FL, CD, 
DLS and field emission scanning electron microscopy. The SEM experiments were done as followed: A drop (about $20 \mu \mathrm{L}$ solution) of the solution $\left(5 \times 10^{-5} \mathrm{M}\right.$ in ethanol/water $\left.(\mathrm{v} / \mathrm{v}, 8: 92)\left[\mathbf{P y D N H}_{3}\right]=5 \times 10^{-5} \mathrm{M},\left[L-\operatorname{TrpCO}_{2}\right]=5 \times 10^{-4} \mathrm{M}\right)$ was put on silica slice and dried at room temperature over $12 \mathrm{~h}$. The sample was then coated with gold in an ion coater for $110 \mathrm{~s}$.

Fluorescence quantum yields for the samples, $\Phi_{\mathrm{F}}$, were calculated in $0.1 \mathrm{M} \mathrm{H}_{2} \mathrm{SO}_{4}$ solutions with quinine sulfate as the reference $\left(\Phi_{\mathrm{F}}=0.53\right)^{1}$ and using equation $\mathbf{1}$ : $\Phi_{\mathrm{F}}=\left(A_{\mathrm{qs}} / A_{\mathrm{s}}\right)\left(I_{\mathrm{s}} / I_{\mathrm{qs}}\right)\left(\eta_{\mathrm{s}} / \eta_{\mathrm{qs}}\right)^{2} \Phi_{\mathrm{qs}}$

Where the subscript s refers to the samples, the subscript qs refers to quinine sulfate, $A$ is the absorbance at the excitation wavelength, $I$ is the integrated emission area, and $\eta$ is the solvent refraction index.

\section{Reference}

1 Adams, M. J.; Highfield, J. G.; Kirkbright, G. F. Anal. Chem. 1977, 49, 1850. 


\section{Synthesis}
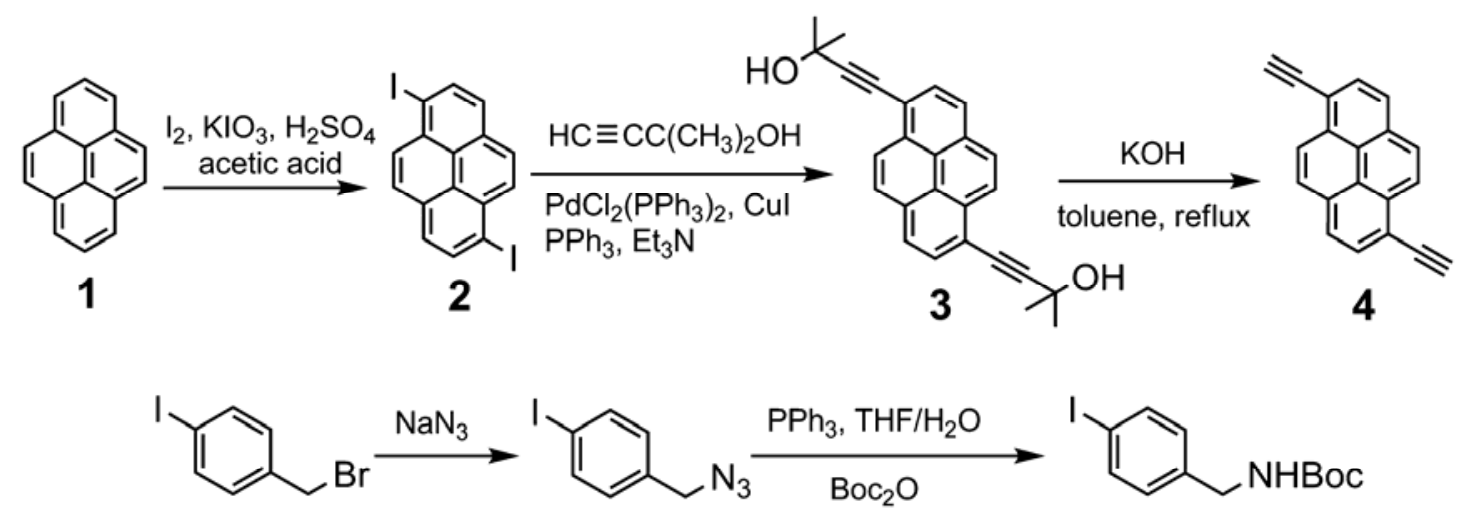

5

6

7

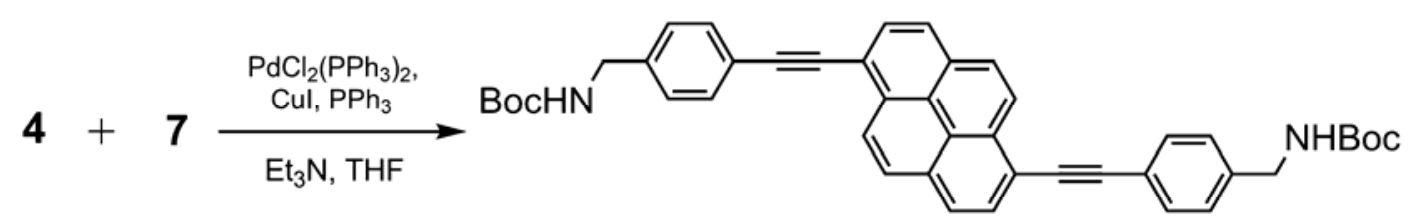

8

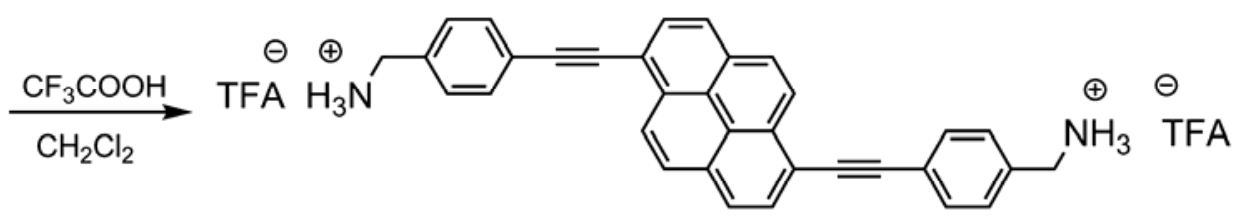

$\mathrm{PyDNH}_{3} 9$

Figure S1. Synthesis of compound $\mathrm{PyDNH}_{3}$.

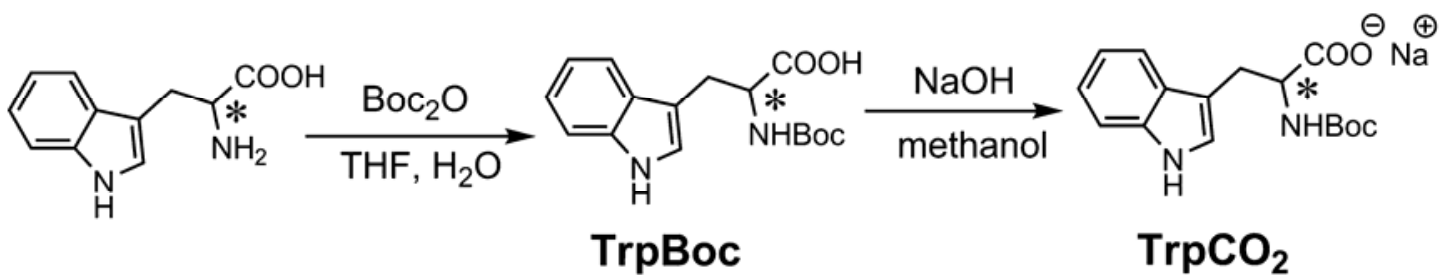

Figure S2. Synthesis of compound $\operatorname{TrpCO} \mathbf{O}_{2}$

Iodination of pyrene (1) afforded a diiodo derivative (2). Subsequent treatment of compound 2 with 2-methyl-3-butyn-2-ol gave the corresponding diols compounds (3) followed by the treatment under basic condition to afford corresponding intermediate 1, 6-bis(ethylnyl)pyrene (4). 4-Iodobenzyl bromide (5) was converted into $N$-Boc 
4-iodobenzyl amine (7) in three steps. Reaction of 1, 6-diethynylpyrene (4) with 7 by Sonogashira reaction gave 8 followed by the cleavage of Boc groups to afford the target compound $\mathbf{P y D N H}$.

Compound (2):

Pyrene $(1,3.0 \mathrm{~g}, 15 \mathrm{mmol})$ was dissolved in acetic acid $(100 \mathrm{~mL})$ at $90{ }^{\circ} \mathrm{C}$. Water $(10 \mathrm{~mL})$, iodine $(4.0 \mathrm{~g}, 15.7 \mathrm{mmol})$, potassium iodate $(1.29 \mathrm{~g}, 6 \mathrm{mmol})$, and concentrated $\mathrm{H}_{2} \mathrm{SO}_{4}(1 \mathrm{~mL})$ were added in that order before cooling to $40{ }^{\circ} \mathrm{C}$. The reaction mixture was stirred at $40^{\circ} \mathrm{C}$ for overnight. After cooling to room temperature, the brown solid was filtered. Water and dichloromethane were added to the solid, the layers were separated, and the aqueous phase was extracted with dichloromethane. The combined organic layers were dried with anhydrous $\mathrm{Na}_{2} \mathrm{SO}_{4}$, and the solvent was removed under reduced pressure. The residue was purified on silica gel with petroleum to give the diiodopyrene mixture.

Compound 4-[6-(3-hydroxy-3-methyl-but-1-ynyl)-pyren-1-yl]-2-methyl-3-butyn2-ol (3):

A mixture of the obtained diiodopyrene mixture (2, $1.31 \mathrm{~g}, 2.9 \mathrm{mmol})$, 2-methyl-3-butyn-2-ol (355 $\mu \mathrm{L}, 6 \mathrm{mmol}), \mathrm{CuI}$ (30 mg, $0.15 \mathrm{mmol}), \mathrm{PPh}_{3}(40 \mathrm{mg}, 0.15$ mmol), and $\mathrm{Pd}\left(\mathrm{PPh}_{3}\right)_{2} \mathrm{Cl}_{2}(105 \mathrm{mg}, 0.15 \mathrm{mmol})$ was stirred at $90{ }^{\circ} \mathrm{C}$ in anhydrous $\mathrm{Et}_{3} \mathrm{~N}$ for $12 \mathrm{~h}$ under nitrogen. After the mixture was cooled to room temperature and filtered, the filtrate was concentrated under reduced pressure. The crude product was purified by column chromatography (silica gel) with dichloromethane/ethyl acetate (100:1, by volume) as eluent to afford 3 (190 mg). ${ }^{1} \mathrm{H}$ NMR (400 MHz, $\mathrm{CDCl}_{3}, 298 \mathrm{~K}$, 
TMS): $\delta=8.53(\mathrm{~s}, 1 \mathrm{H}), 8.51(\mathrm{~s}, 1 \mathrm{H}), 8.12-8.09(\mathrm{~m}, 6 \mathrm{H}), 2.19(\mathrm{~s}, 2 \mathrm{H}), 1.79(\mathrm{~s}, 12 \mathrm{H})$ MS (EI): $366[\mathrm{M}]^{+}$.

Compound 1, 6-diethynylpyrene (4):

A mixture

of 4-[6-(3-hydroxy-3-methyl-but-1-ynyl)-pyren-1-yl]-2-methyl-3-butyn-2-ol (3, $190 \mathrm{mg}$, $0.53 \mathrm{mmol})$ and $\mathrm{KOH}(65 \mathrm{mg}, 1.17 \mathrm{mmol})$ in toluene $(50 \mathrm{~mL})$ was heated at reflux for $4 \mathrm{~h}$. After the mixture was cooled to room temperature, the organic layer was washed with water and dried over sodium sulfate. The solvent was removed under reduced pressure and the crude product was purified by column chromatography (silica gel) with petroleum as eluent to give 4 (80 mg, 61\%). ${ }^{1} \mathrm{H} \mathrm{NMR}\left(400 \mathrm{MHz}, \mathrm{CDCl}_{3}, 298 \mathrm{~K}\right.$, TMS): $\delta=8.63(\mathrm{~s}, 1 \mathrm{H}), 8.61(\mathrm{~s}, 1 \mathrm{H}), 8.20-8.13(\mathrm{~m}, 6 \mathrm{H}), 3.64(\mathrm{~s}, 2 \mathrm{H}) . \mathrm{MS}(\mathrm{EI}): 250$ $[\mathrm{M}]^{+}$.

Compound 4-iodobenzyl azide (6):

A solution of 4-iodo-benzyl bromide (5, $1.5 \mathrm{~g}, 5.0 \mathrm{mmol})$ in DMSO (80 $\mathrm{mL})$ was treated with sodium azide (394 mg, $6 \mathrm{mmol}$ ) and stirred at $60{ }^{\circ} \mathrm{C}$ for $12 \mathrm{~h}$. After cooling to room temperature, water and $\mathrm{Et}_{2} \mathrm{O}$ were added, the layers were separated, and the aqueous phase was extracted with $\mathrm{Et}_{2} \mathrm{O}$. The combined organic layers were dried with $\mathrm{Na}_{2} \mathrm{SO}_{4}$, and the solvent was removed under reduced pressure. The obtained product was directly used for the next reaction without purification.

Compound tert-Butyl $N$-(4-iodobenzyl)carbamate (7):

A solution of 4-iodobenzyl azide $(6,1.30 \mathrm{~g}, 5.0 \mathrm{mmol})$ in $\mathrm{THF} / \mathrm{H}_{2} \mathrm{O}(90 \mathrm{~mL} / 10 \mathrm{~mL})$ was treated with $\mathrm{PPh}_{3}(1.45 \mathrm{~g}, 5.5 \mathrm{mmol})$ and the mixture was stirred at room 
temperature for $12 \mathrm{~h}$. The solvent was removed under reduced pressure and di-tert-butyldicarbonate $(1.31 \mathrm{~g}, 5.5 \mathrm{mmol})$ in $30 \mathrm{~mL}$ of dried THF was added. The resulting solution was stirred at room temperature for $2 \mathrm{~h}$. The solvent was removed under reduced pressure and the residue was purified by silica gel column chromatography using petroleum $/ \mathrm{CH}_{2} \mathrm{Cl}_{2}(\mathrm{v} / \mathrm{v}, 3: 1)$. The product was obtained as white solid (791 mg, 47\%). ${ }^{1} \mathrm{H}$ NMR (400 MHz, $\left.\mathrm{CDCl}_{3}, 298 \mathrm{~K}, \mathrm{TMS}\right): \delta=7.64$ (d, $J=$ $8.0 \mathrm{~Hz}, 2 \mathrm{H}), 7.03(\mathrm{~d}, J=8.0 \mathrm{~Hz}, 2 \mathrm{H}), 4.86(\mathrm{bs}, 1 \mathrm{H}), 4.25(\mathrm{~d}, J=5.6 \mathrm{~Hz}, 2 \mathrm{H}), 1.45(\mathrm{~s}$, 9H). ${ }^{13} \mathrm{C}$ NMR (100 MHz, $\left.\mathrm{CDCl}_{3}, 298 \mathrm{~K}, \mathrm{TMS}\right): 156.0,138.9,137.7,129.5,92.7,79.8$, 44.2, 28.5. EI-MS: $333[\mathrm{M}]^{+}$.

Compound (8):

A mixture of 1,6-diethynylpyrene $(4,50 \mathrm{mg}, \quad 0.2 \mathrm{mmol})$, tert-Butyl $N$-(4-iodobenzyl)carbamate (7, $166 \mathrm{mg}, 0.5 \mathrm{mmol}), \mathrm{CuI}(2 \mathrm{mg}, 0.01 \mathrm{mmol}), \mathrm{PPh}_{3},(3$ mg, $0.01 \mathrm{mmol})$, and $\mathrm{PdCl}_{2}\left(\mathrm{PPh}_{3}\right)_{2}(7 \mathrm{mg}, 0.01 \mathrm{mmol})$ in anhydrous $\mathrm{Et}_{3} \mathrm{~N} / \mathrm{THF}(\mathrm{v} / \mathrm{v}$, $90 \mathrm{~mL} / 10 \mathrm{~mL}$ ) was stirred for $12 \mathrm{~h}$ at $90{ }^{\circ} \mathrm{C}$ under nitrogen. After cooling to room temperature, the mixture was filtered and concentrated under reduced pressure. The residue was purified by silica gel column chromatography with dichloromethane/ethyl acetate as eluent to give compound 8 (45 mg, 34\%). ${ }^{1} \mathrm{H}$ NMR (600 $\mathrm{MHz}, \mathrm{CDCl}_{3}$, 298K, TMS): $\delta=8.65(\mathrm{~d}, J=9.0 \mathrm{~Hz}, 2 \mathrm{H}), 8.19(\mathrm{~d}, J=7.8 \mathrm{~Hz}, 2 \mathrm{H}), 8.14(\mathrm{t}, 4 \mathrm{H}), 7.67$ (d, $J=7.8 \mathrm{~Hz}, 4 \mathrm{H}), 7.34(\mathrm{~d}, J=7.8 \mathrm{~Hz}, 4 \mathrm{H}) 4.89(\mathrm{bs}, 2 \mathrm{H}), 4.37$ (d, $J=4.2 \mathrm{~Hz}, 2 \mathrm{H})$, 1.49 (s, 18H). ${ }^{13} \mathrm{C}$ NMR (150 MHz, $\left.\mathrm{CDCl}_{3}, 298 \mathrm{~K}, \mathrm{TMS}\right): 155.9,139.6,132.0,131.9$, $131.2,129.9,128.1,127.5,127.4,126.2,125.1,124.2,122.4,118.5,95.3,88.6,79.7$, 44.6, 29.7, 28.4. MALDI-TOF MS: Calcd. for $\mathrm{C}_{44} \mathrm{H}_{40} \mathrm{~N}_{2} \mathrm{O}_{4}[\mathrm{M}]^{+}=660.3$ found, 
$[\mathrm{M}+1]^{+}=661.1$

Compound $\mathbf{P y D N H}_{3}(\mathbf{9})$ :

A solution of $8(30 \mathrm{mg}, 0.045 \mathrm{mmol})$ in $\mathrm{CH}_{2} \mathrm{Cl}_{2}(10 \mathrm{~mL})$ at $0{ }^{\circ} \mathrm{C}$ was treated with $\mathrm{CF}_{3} \mathrm{COOH}(1 \mathrm{~mL})$. After being stirred at room temperature for $1 \mathrm{~h}$, the reaction mixture was evaporated and the residue was diluted with EtOAc and concentrated under reduced pressure to give compound $\mathbf{P y D N H}_{3}$ (25 mg, 86\%). ${ }^{1} \mathrm{H}$ NMR (400 MHz, $d_{6}$-DMSO, 298K, TMS): $\delta=8.71(\mathrm{~d}, J=8.0 \mathrm{~Hz}, 2 \mathrm{H}), 8.46-8.41(\mathrm{~m}, 4 \mathrm{H}), 8.37$ (d, $J=8.0 \mathrm{~Hz}, 2 \mathrm{H}), 8.23(\mathrm{bs}, 6 \mathrm{H}), 7.88(\mathrm{~d}, J=8.0 \mathrm{~Hz}, 4 \mathrm{H}), 7.62(\mathrm{~d}, J=8.0 \mathrm{~Hz}, 4 \mathrm{H})$, 4.00 (bs, 4H). ${ }^{13} \mathrm{C}$ NMR (150 MHz, $d_{6}$-DMSO, 298K, TMS): 135.3, 132.2, 131.7, $131.4,130.7,129.8,129.3,126.4,123.8,122.9,117.9,95.8,89.2,42.5$. ESI $\mathrm{m} / \mathrm{z}$ : Calcd. for $\mathrm{C}_{34} \mathrm{H}_{26} \mathrm{~N}_{2}[\mathrm{M}+2 \mathrm{H}]^{+}=462.2$ found, 461.7 .

\section{Compound TrpBoc:}

$\mathrm{NaOH}(88 \mathrm{mg}, 1.1 \mathrm{mmol})$ and $\mathrm{Boc}_{2} \mathrm{O}(240 \mathrm{mg}, 1.1 \mathrm{mmol})$ were added to a stirred solution of L-tryptophan $(204 \mathrm{mg}, 1 \mathrm{mmol})$ in $\mathrm{THF} / \mathrm{H}_{2} \mathrm{O}(\mathrm{v} / \mathrm{v}, 10 \mathrm{~mL}: 10 \mathrm{~mL})$ at room temperature and the resulting solution was stirred for $18 \mathrm{~h}$. THF was removed under reduced pressure and the aqueous layer was extracted with dichloromethane. The aqueous layer was acidified with $\mathrm{HCl}(1 \mathrm{~N})$ to $\mathrm{pH}$ 4, and then extracted with dichloromethane. The organic phase was dried over $\mathrm{Na}_{2} \mathrm{SO}_{4}$ and the solvent was evaporated under reduced pressure to give the compound TrpBoc $(271 \mathrm{mg}, 89 \%) .{ }^{1} \mathrm{H}$ NMR (400 MHz, $\left.\mathrm{CDCl}_{3}, 298 \mathrm{~K}, \mathrm{TMS}\right): \delta=8.06(\mathrm{bs}, 1 \mathrm{H}), 7.60(\mathrm{~d}, J=8.0 \mathrm{~Hz}, 1 \mathrm{H})$, $7.36(\mathrm{~d}, J=8.0 \mathrm{~Hz}, 1 \mathrm{H}), 7.21(\mathrm{t}, 1 \mathrm{H}), 7.13(\mathrm{t}, 1 \mathrm{H}), 7.03(\mathrm{~s}, 1 \mathrm{H}), 5.02(\mathrm{~s}, 1 \mathrm{H}), 4.65(\mathrm{~s}$, 1H), 3.37-3.33 (b, 2H), $1.43(\mathrm{~s}, 9 \mathrm{H})$. 


\section{Compound TrpCO : $^{2}$}

$\mathrm{NaOH}$ (13.2 mg, $0.33 \mathrm{mmol})$ was added to a stirred solution of TrpBoc (100 mg, $0.33 \mathrm{mmol})$ in methanol $(30 \mathrm{~mL})$ at room temperature and the mixture was stirred for $10 \mathrm{~min}$. The solvent was removed under reduced pressure at $0{ }^{\circ} \mathrm{C}$ to give the compound $\operatorname{TrpCO}_{2}$ (104 mg, 97\%). FT-IR (KBr): 3395, 3055, 2976, 2931, 1683, $1590,1507,1454,1400,1249,1169,1055,743 \mathrm{~cm}^{-1} .{ }^{1} \mathrm{H}$ NMR (400 MHz, $d_{6}$-DMSO, 298K, TMS): $\delta=10.63(\mathrm{~s}, 1 \mathrm{H}), 7.47(\mathrm{~d}, J=8.0 \mathrm{~Hz}, 1 \mathrm{H}), 7.25(\mathrm{~d}, J=8.0 \mathrm{~Hz}, 1 \mathrm{H})$, $6.99(\mathrm{~s}, 1 \mathrm{H}), 6.88-6.85(\mathrm{~m}, 1 \mathrm{H}), 5.77(\mathrm{~d}, J=4 \mathrm{~Hz}, 1 \mathrm{H}), 3.70(\mathrm{~s}, 1 \mathrm{H}), 3.19-3.16(\mathrm{~m}$, 1H), .3.03-2.99 (m, 1H), $1.34(\mathrm{~s}, 9 \mathrm{H})$. 

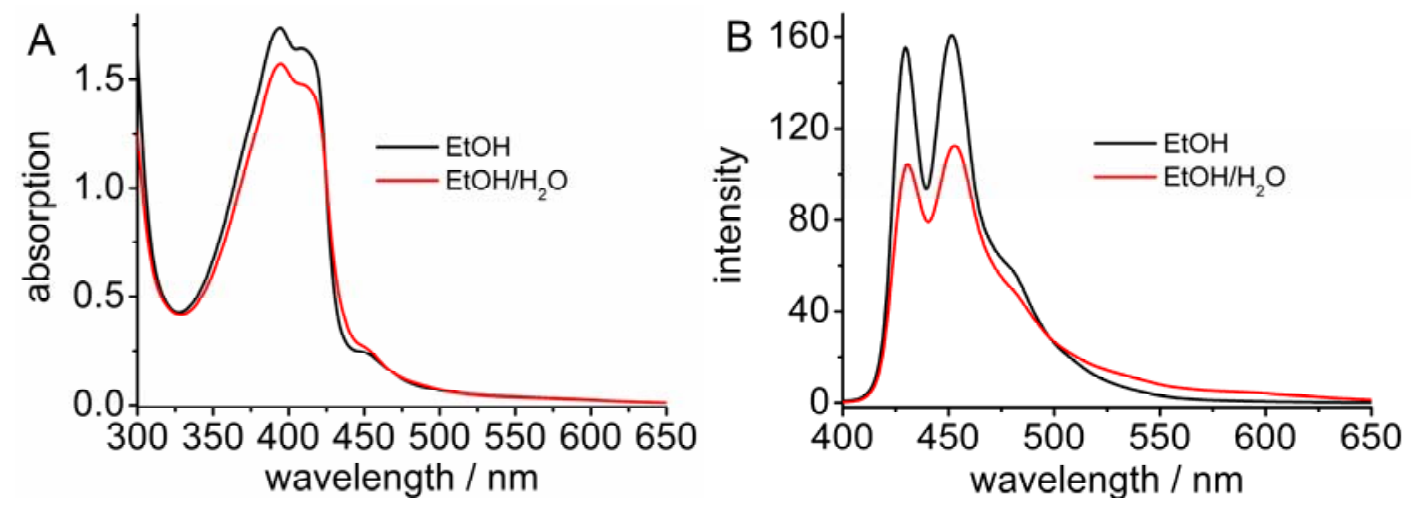

Figure S3. UV-vis absorption (A) and Fluorescence spectra (excitation at $390 \mathrm{~nm}$ ) (B) in ethanol and ethanol/water (v/v, 8:92) mixture: $\left[\mathbf{P y D N H}_{3}\right]=5 \times 10^{-5} \mathrm{M}$.

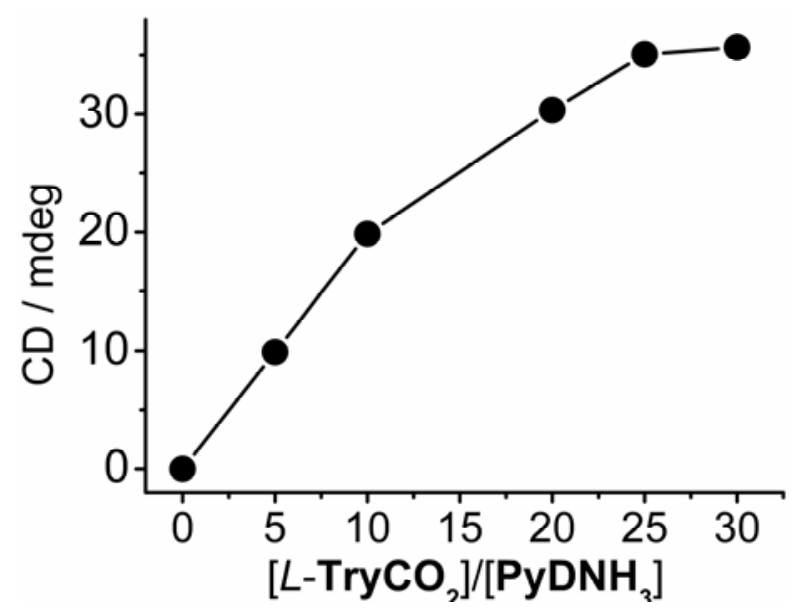

Figure S4. The titration curves of $\mathbf{P y D N H}_{3}\left([\theta]_{452}\right)$ with $L-\operatorname{TrpCO} \mathbf{O}_{2}$ 


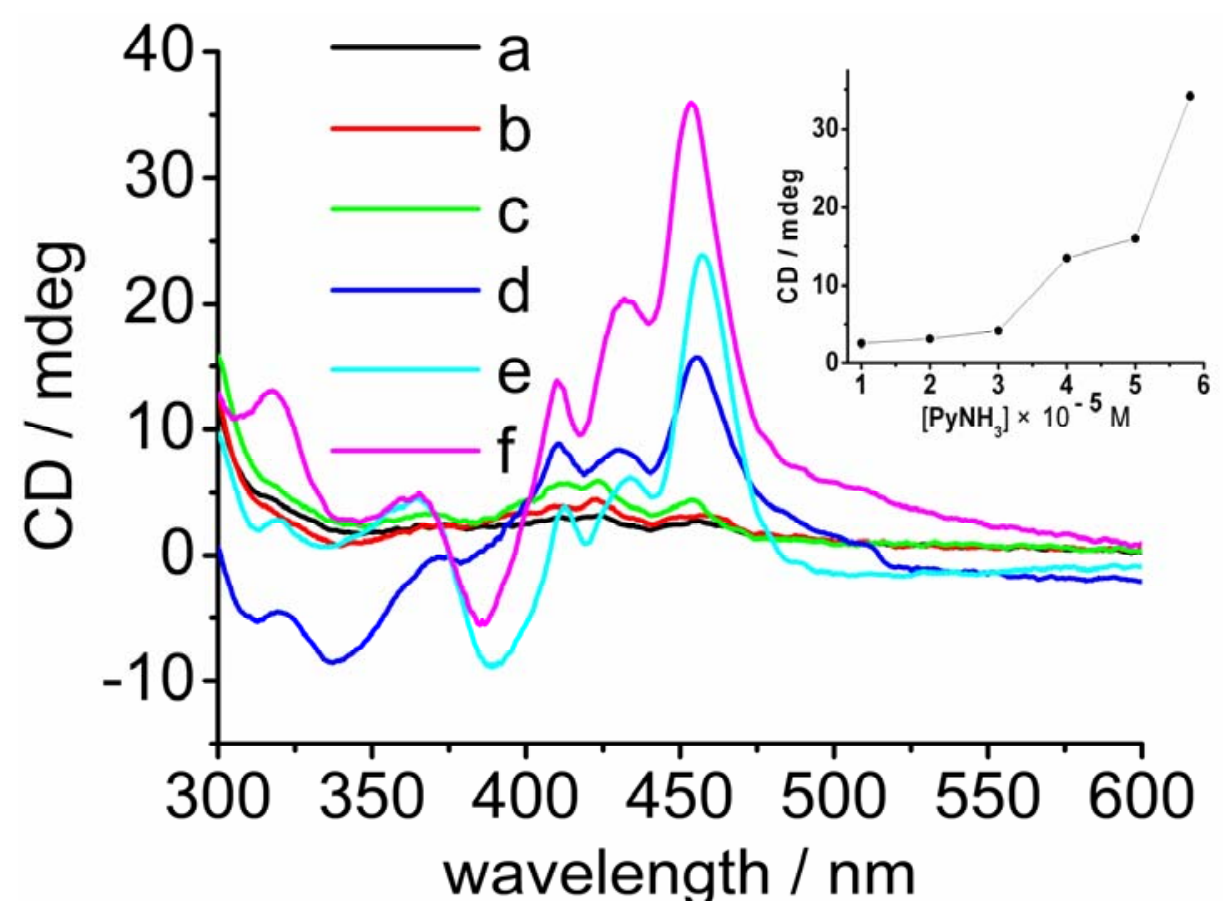

Figure S5. CD spectra titration of $\mathbf{P y D N H}_{3}$ to $L-\mathbf{T r p C O} \mathbf{O}_{2}$ in ethanol/water (v/v, 8:92) mixture: $\left[L-\operatorname{TrpCO}_{2}\right]=5.0 \times 10^{-4} \mathrm{M},\left[\mathbf{P y D N H}_{3}\right]=$ (a) $1.0 \times 10^{-5} \mathrm{M}$, (b) $2.0 \times 10^{-5} \mathrm{M}$, (c) $3.0 \times 10^{-5} \mathrm{M}$, (d) $4.0 \times 10^{-5} \mathrm{M}$, (e) $5.0 \times 10^{-5} \mathrm{M}$, (f) $5.8 \times 10^{-5} \mathrm{M},[\mathrm{pH}]=2.5$; Inset shows the titration curves of $L-\operatorname{TrpCO} \mathbf{O}_{2}\left([\theta]_{452}\right)$ with $\mathbf{P y D N H}_{3}$.

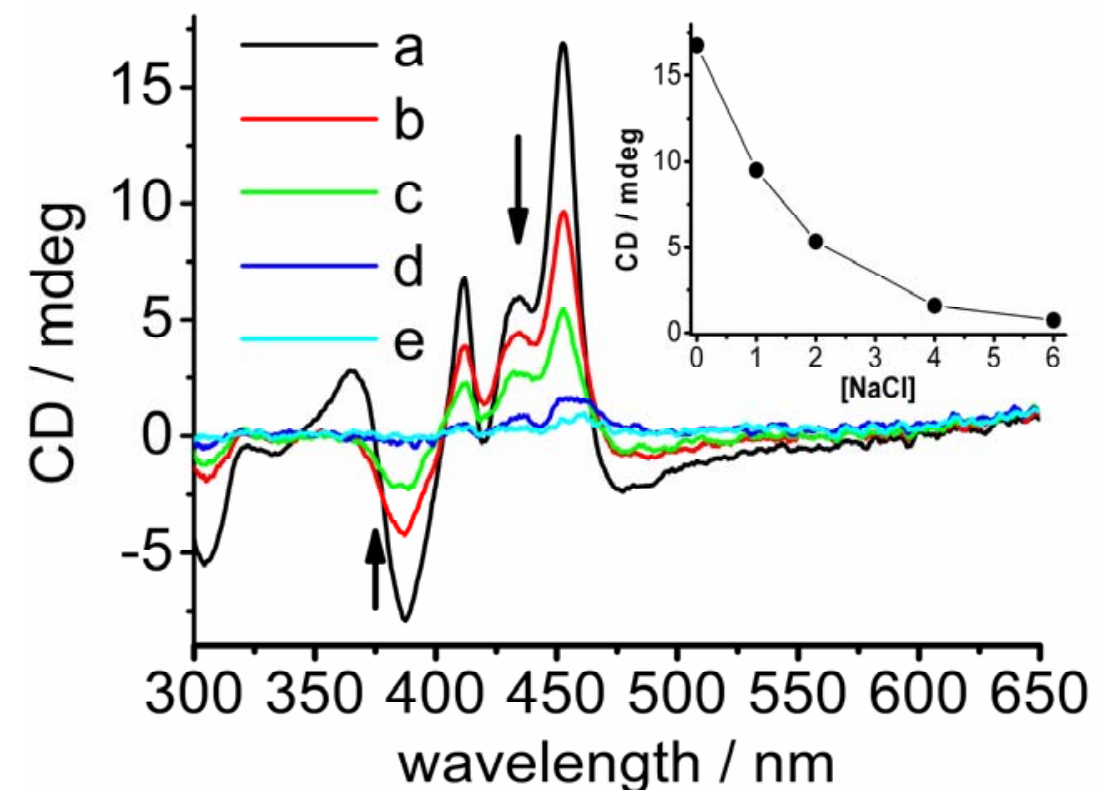

Figure S6. CD spectra of complex in ethanol/water (v/v, 8:92) mixture: $\left[\mathbf{P y D N H}_{3}\right]=$ $5 \times 10^{-5} \mathrm{M},\left[L-\operatorname{TrpCO}_{2}\right]=5.0 \times 10^{-4} \mathrm{M},[\mathrm{pH}]=2.5,[\mathrm{NaCl}]=(\mathrm{a}) 0$, (b) $2.5 \times 10^{-2} \mathrm{M}$, (c) $5.0 \times 10^{-2} \mathrm{M}$, (d) $0.1 \mathrm{M}$, (e) $0.15 \mathrm{M}$. Inset shows the dependence of ICD intensity $\left([\theta]_{452}\right)$ of complex $\mathbf{P y D N H}_{3} / L-\mathbf{T r p C O}_{2}$ on $\mathrm{NaCl}$ concentration. 

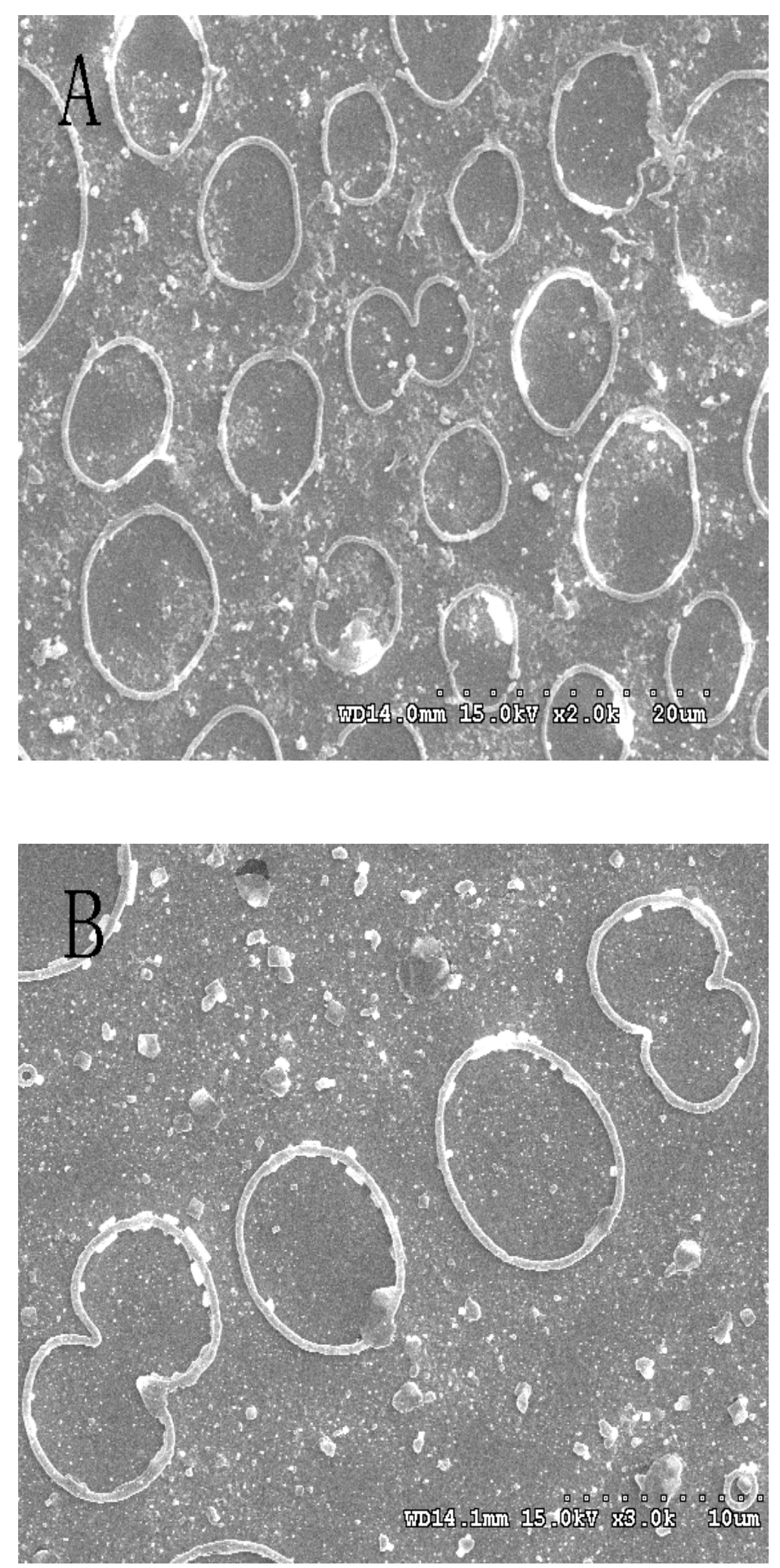


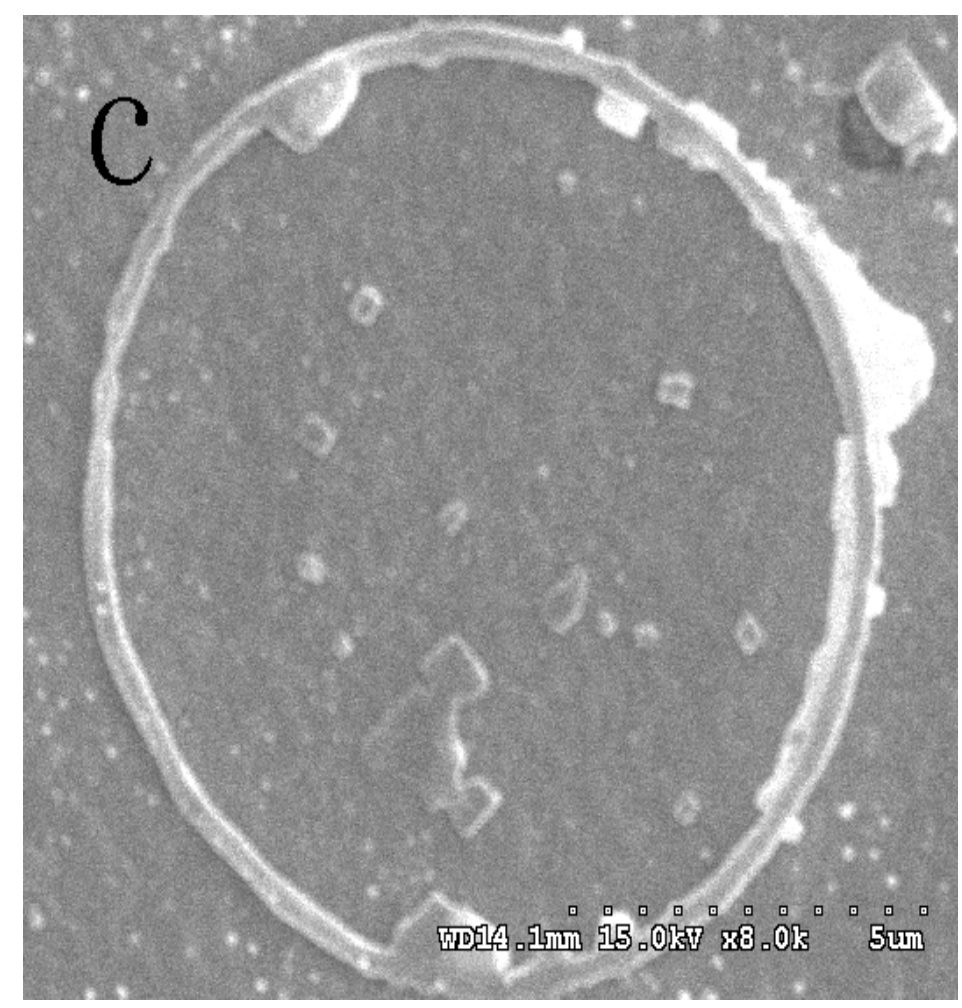

Figure S7. SEM images of self-assembly $\mathbf{P y D N H}_{3} / L-\mathbf{T r p C O}_{2}$ in ethanol/water (v/v, 8:92). (A) a large area of ring structures, (B) different morphologies of ring structures, (C) an independent ring structure.
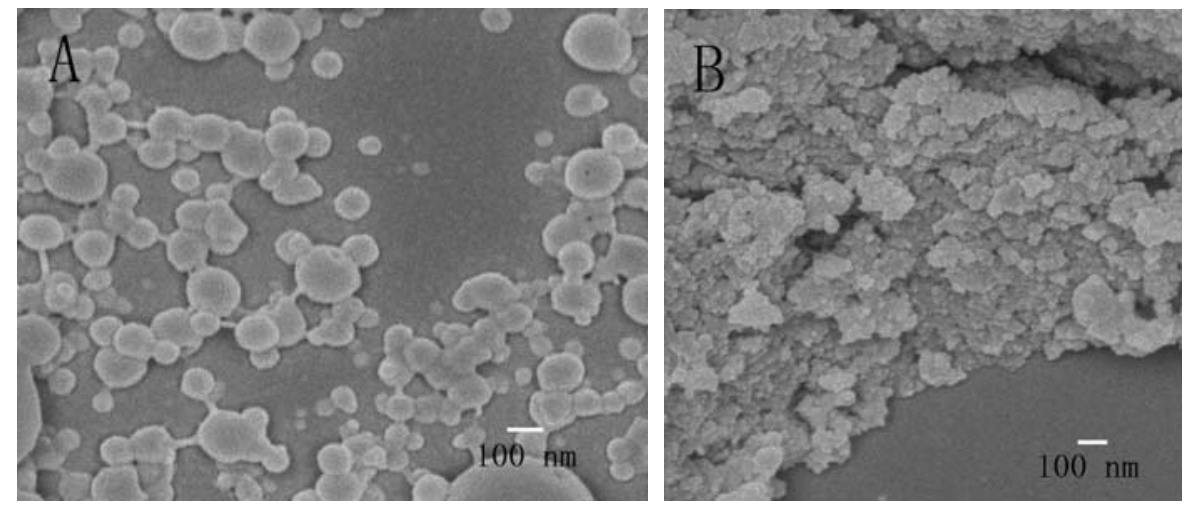

Figure S8. SEM images of self-assembly $\mathbf{P y D N H}_{3} / L$-TrpCO $\mathbf{C O}_{2}$ in (A) ethanol/water $(\mathrm{v} / \mathrm{v}, 8: 92),(\mathrm{B}) \mathbf{P y D N H}_{3}$ in ethanol, $\left[\mathbf{P y D N H}_{3}\right]=5 \times 10^{-5} \mathrm{M},\left[L-\mathbf{T r p C O}_{2}\right]=5 \times 10^{-4}$ M. 

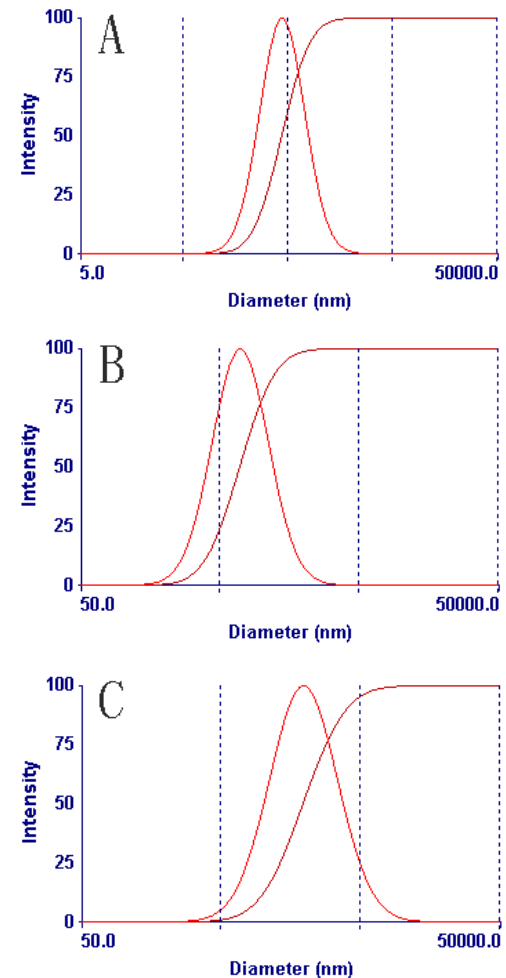

Figure S9. Dynamic laser scattering of the complex at a scattering angle of $90^{\circ},(\mathrm{A})$ $\left[\right.$ PyDNH $\left._{3}\right]=5 \times 10^{-5} \mathrm{M}$ in ethanol, (B) $\left[\mathbf{P y D N H}_{3}\right]=5 \times 10^{-5} \mathrm{M}$, in ethanol $/$ water $(\mathrm{v} / \mathrm{v}$, $8: 92),(\mathrm{C})\left[\mathbf{P y D N H}_{3}\right]=5 \times 10^{-5} \mathrm{M},\left[L-\operatorname{TrpCO}_{2}\right]=5 \times 10^{-4} \mathrm{M}$, in ethanol/water $(\mathrm{v} / \mathrm{v}$, 8:92). 


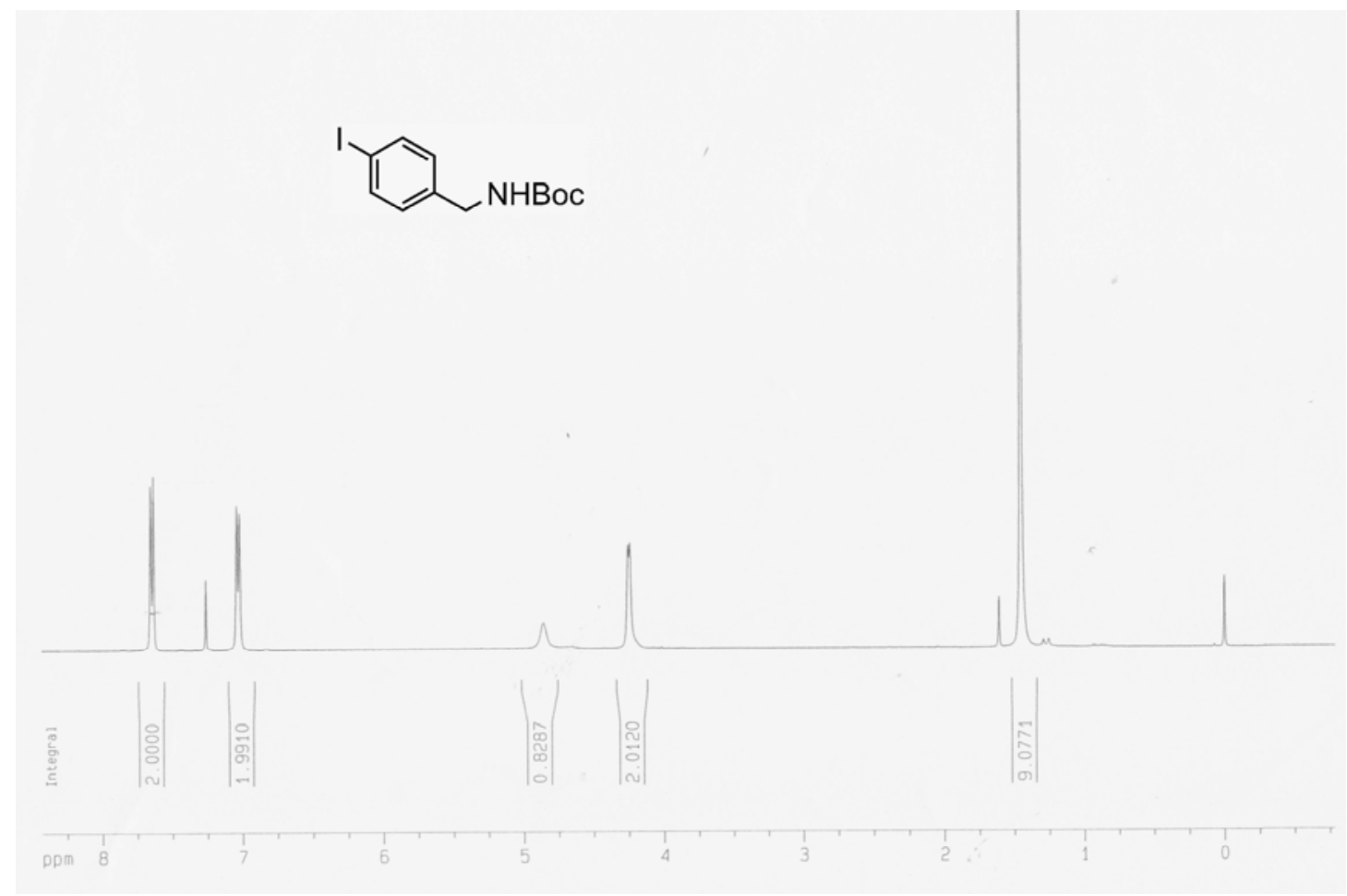

Figure S10. ${ }^{1} \mathrm{H}$ NMR spectra of compound 7 in $\mathrm{CDCl}_{3}$.

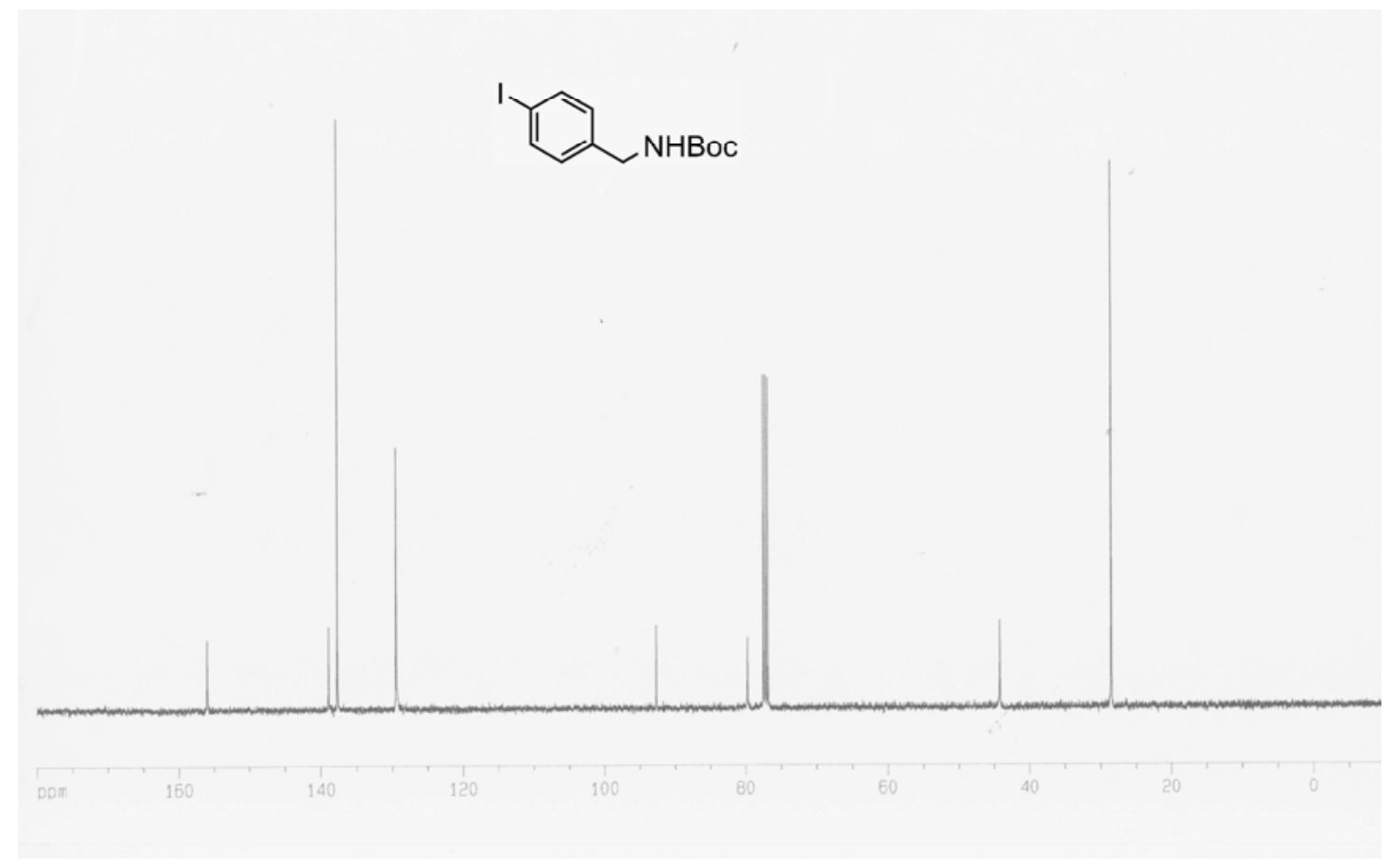

Figure S11. ${ }^{13} \mathrm{C}$ NMR spectra of compound 7 in $\mathrm{CDCl}_{3}$. 


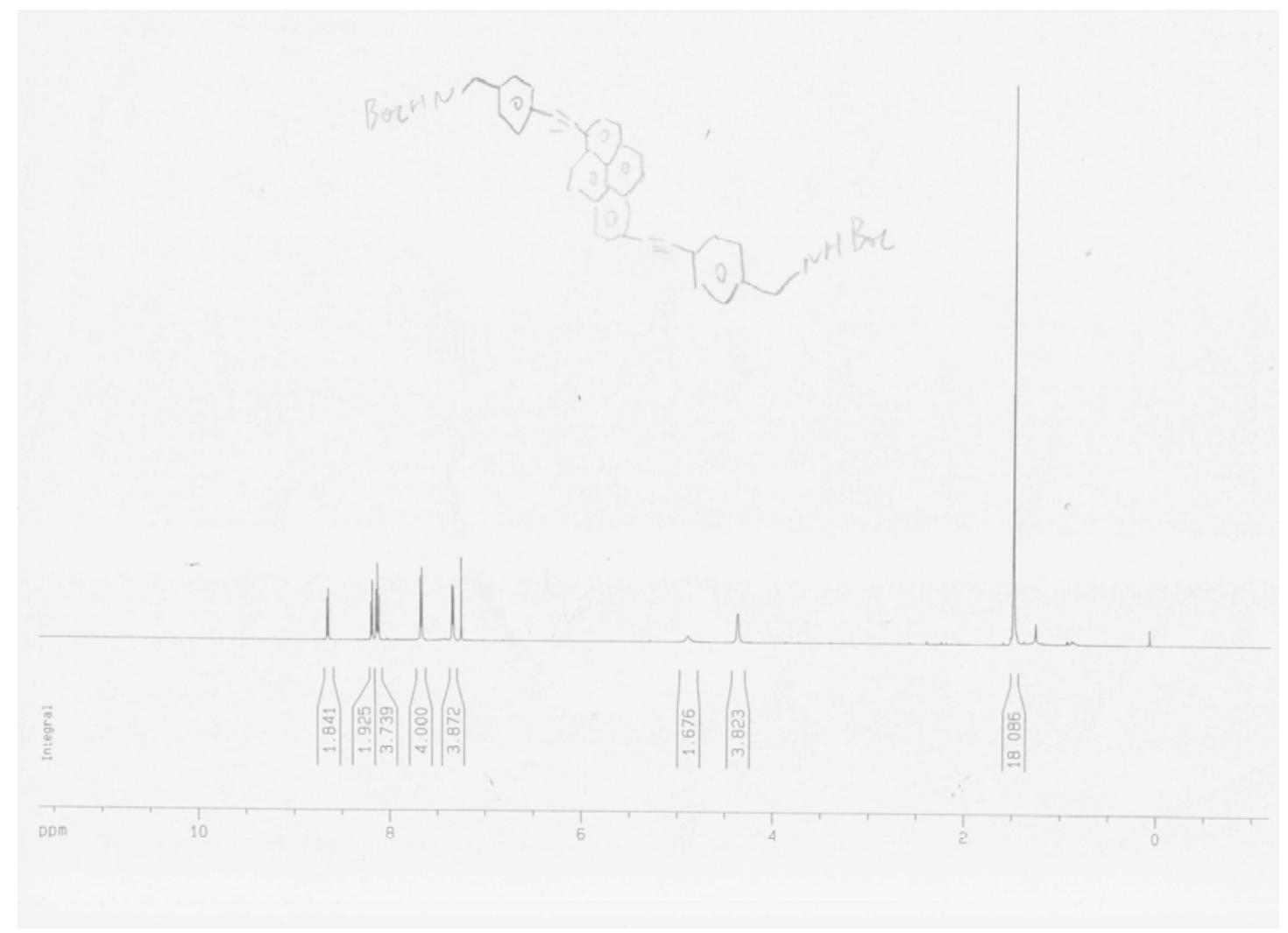

Figure S12. ${ }^{1} \mathrm{H}$ NMR spectra of compound 8 in $\mathrm{CDCl}_{3}$.

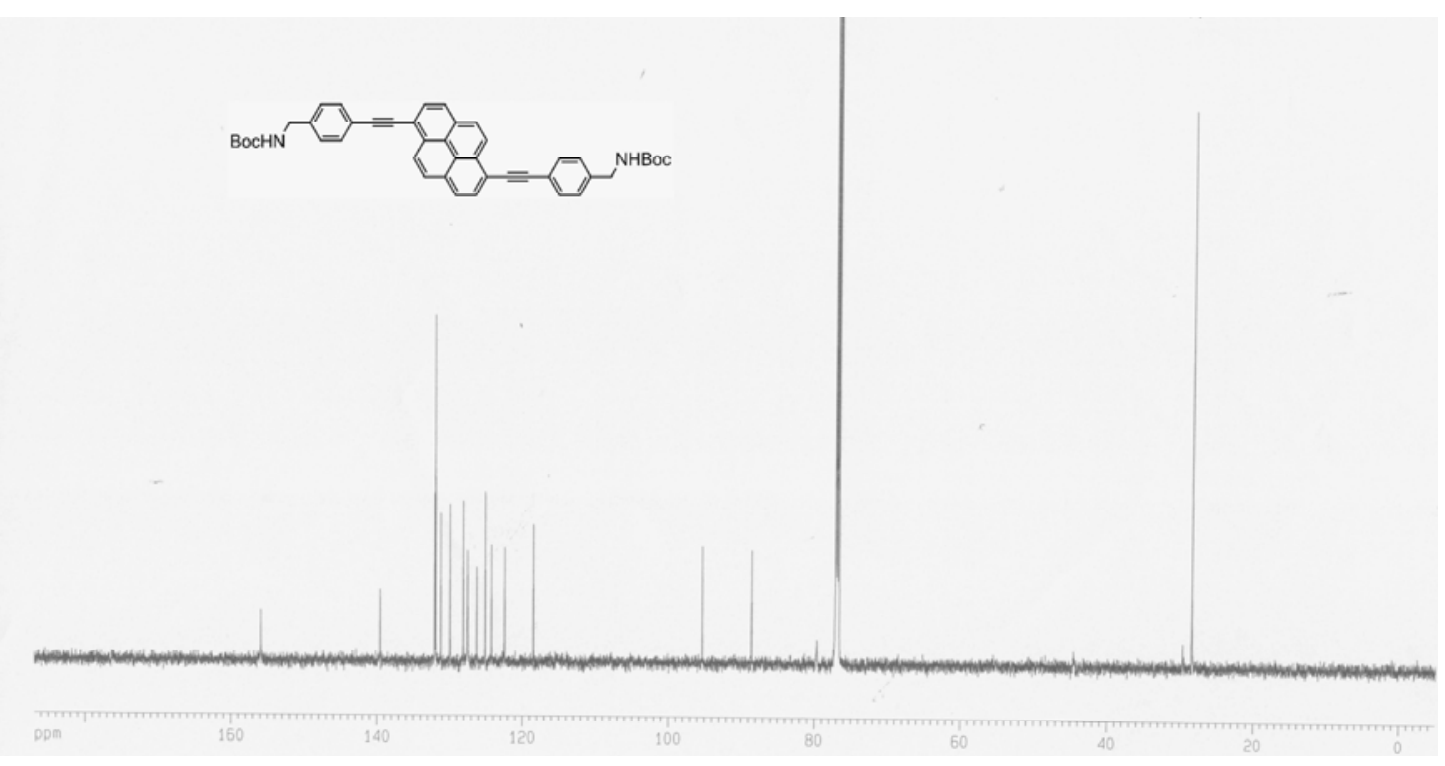

Figure S13. ${ }^{13} \mathrm{C}$ NMR spectra of compound 8 in $\mathrm{CDCl}_{3}$. 


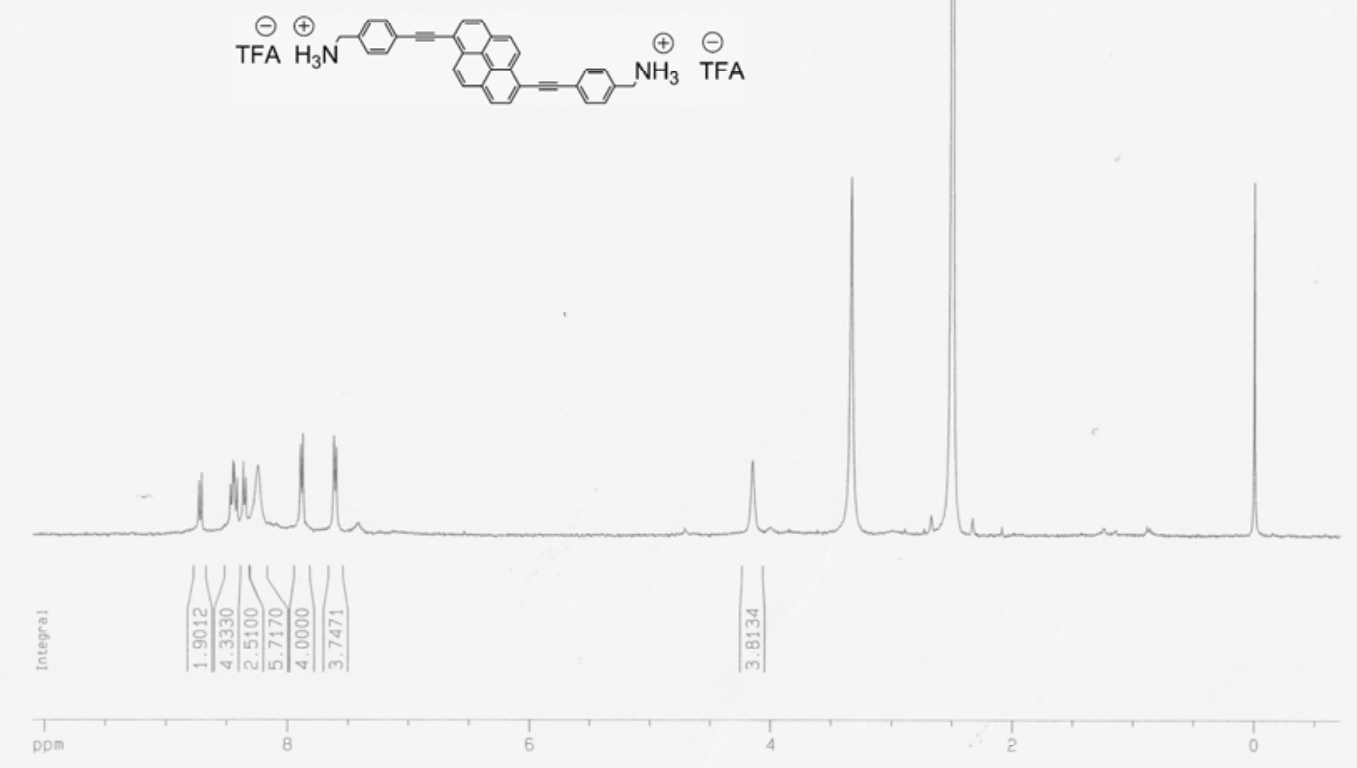

Figure S14. ${ }^{1} \mathrm{H}$ NMR spectra of compound 9 in $d_{6}$-DMSO.

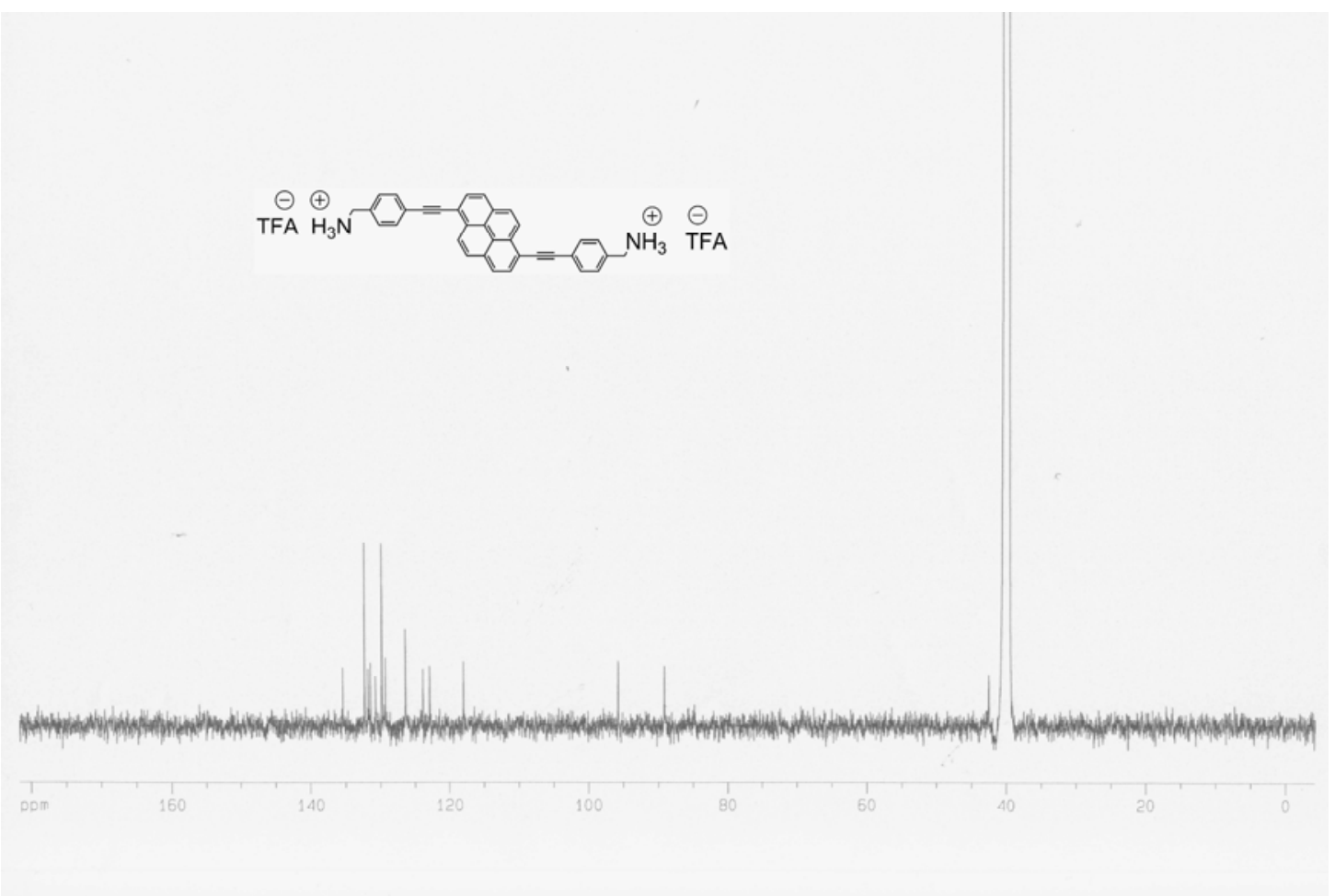

Figure S15. ${ }^{13} \mathrm{C}$ NMR spectra of compound 9 in $d_{6}$-DMSO. 


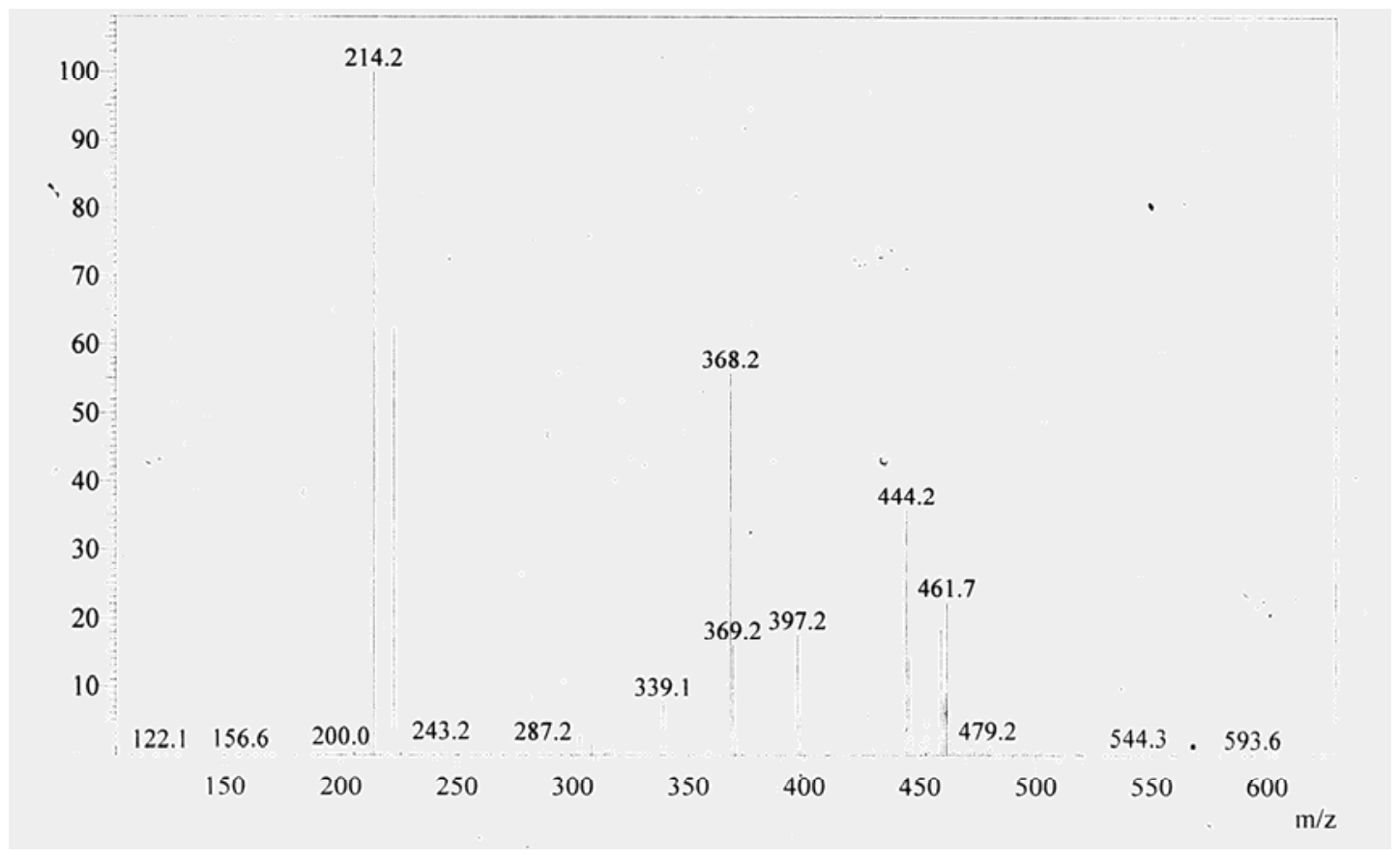

Figure S16. ESI spectra of compound 9. 